University of Nebraska - Lincoln

DigitalCommons@University of Nebraska - Lincoln

\title{
A quantitative phosphorus loss assessment tool for agricultural fields
}

\author{
Michael J. White \\ USDA-ARS, mike.white@ars.usda.gov \\ Daniel E. Storm \\ Oklahoma State University \\ Philip R. Busteed \\ USDA-ARS, Phil.Busteed@ars.usda.gov \\ Michael D. Smolen \\ Oklahoma State University \\ Hailin Zhang \\ Oklahoma State University \\ See next page for additional authors
}

Follow this and additional works at: https://digitalcommons.unl.edu/usdaarsfacpub

Part of the Agricultural Science Commons

White, Michael J.; Storm, Daniel E.; Busteed, Philip R.; Smolen, Michael D.; Zhang, Hailin; and Fox, Garey A., "A quantitative phosphorus loss assessment tool for agricultural fields" (2010). Publications from USDAARS / UNL Faculty. 1066.

https://digitalcommons.unl.edu/usdaarsfacpub/1066

This Article is brought to you for free and open access by the U.S. Department of Agriculture: Agricultural Research Service, Lincoln, Nebraska at DigitalCommons@University of Nebraska - Lincoln. It has been accepted for inclusion in Publications from USDA-ARS / UNL Faculty by an authorized administrator of DigitalCommons@University of Nebraska - Lincoln. 


\section{Authors}

Michael J. White, Daniel E. Storm, Philip R. Busteed, Michael D. Smolen, Hailin Zhang, and Garey A. Fox 
Position Paper

\title{
A quantitative phosphorus loss assessment tool for agricultural fields
}

\author{
Michael J. White ${ }^{\mathrm{a}, *}$, Daniel E. Storm ${ }^{\mathrm{b}}$, Philip R. Busteed ${ }^{\mathrm{c}}$, Michael D. Smolen ${ }^{\mathrm{b}}$, Hailin Zhang ${ }^{\mathrm{d}}$, \\ Garey A. Fox ${ }^{\mathrm{b}}$ \\ ${ }^{a}$ USDA-ARS Grassland, Soil, and Water Research Laboratory, 808 East Blackland Road Temple, TX 76502, USA \\ ${ }^{\mathrm{b}}$ Biosystems and Agricultural Engineering Department, Oklahoma State University, 110 Agriculture Hall Stillwater, OK 74078, USA \\ ${ }^{c}$ USDA-ARS Grazinglands Research Laboratory, 7207 West Cheyenne St. El Reno, OK 73036, USA \\ ${ }^{\mathrm{d}}$ Plant and Soil Sciences Department, Oklahoma State University, 368 Agriculture Hall Stillwater, OK 74078, USA
}

\section{A R T I C L E I N F O}

\section{Article history:}

Received 18 March 2009

Received in revised form

16 March 2010

Accepted 17 March 2010

Available online 18 April 2010

\section{Keywords:}

Spatial targeting

Farmland preservation

SWAT

Modeling

Watershed management

Nutrients

Nonpoint source pollution

\begin{abstract}
A B S T R A C T
In the United States, government sponsored conservation programs are under increasing pressure to quantify the environmental benefits of practices they subsidize. To meet this objective, conservation planners need tools to accurately predict phosphorus $(\mathrm{P})$ loss from agricultural lands. Existing $\mathrm{P}$ export coefficient based tools are easy to use, but do not adequately account for local conditions. Hydrologic and water quality models are more accurate, but are prohibitively complex for conservation planners to use. Pasture Phosphorus Management (PPM) Plus was developed as a user-friendly P and sediment loss prediction tool based on the Soil and Water Assessment Tool (SWAT), a popular comprehensive hydrologic and water quality model. PPM Plus is applicable under a wide variety of management options and conservation practices and simple enough for use by conservation planners. SWAT hydrologic components were calibrated to allow application anywhere in the State of Oklahoma. The SWAT model was modified to include soil $P$ algorithm updates and improved representation of conservation practices. This tool was successfully validated using 286 field years of measured data from the southern United States. PPM Plus allows the development of more effective conservation plans by allowing planners to evaluate pollutant losses resulting from a particular management strategy prior to implementation.
\end{abstract}

Published by Elsevier Ltd.

\section{Software availability}

Developer: Pasture Phosphorus Management (PPM) Plus was developed by the Biosystems and Agricultural Engineering and Plant and Soil Sciences Departments at Oklahoma State University.

Availability: PPM Plus is freeware, contact the corresponding author for availability and distribution information.

\section{Introduction}

Phosphorus (P) is an essential nutrient for life, and occurs naturally in the environment. In excess it may significantly impair

Abbreviations: BMP, best management practice; $\mathrm{CN}$, curve number; EPIC, erosion productivity impact calculator; HRU, hydraulic response unit; MUSLE modified universal soil loss equation; $\mathrm{N}$, nitrogen; PPM, pasture phosphorus management; P, phosphorus; ESCO, soil evaporation compensation factor; SWAT, soil and water assessment tool; SSURGO, soil survey geographic; STP, soil test phosphorus; STATSGO, state soil geographic.

* Corresponding author. Tel: +1 254770 6523; fax: +1 2547706561 .

E-mail address: mike.white@ars.usda.gov (M.J. White). water quality by accelerating the growth of algae and aquatic plants. Reducing $\mathrm{P}$ is often considered the most effective strategy for controlling excessive algal growth (Schindler, 1978).

Agricultural production uses $\mathrm{P}$ extensively and is the leading source of impairment for streams and rivers in the US (USEPA, 2007a). To help mitigate this issue in the United States, the Clean Water Act, Section 319 program administered by the US Environmental Protection Agency (USEPA) distributed 204 million dollars in federal funds (with $40 \%$ state match) to states for use in nonpoint source pollution projects in 2007 (USEPA, 2007b). The USEPA now requires measures of 319-program success, including implementation milestones, available reduction estimates for nonpoint source pollutant loads and information on water quality improvements (Hardy and Koontz, 2008). Tools to evaluate P loss in response to conservation practice establishment occupy a spectrum of complexity ranging from simple static export coefficients to dynamic process based models (Radcliffe et al., 2009).

The most commonly used tools to evaluate conservation practices for the USEPA are based on simple export coefficients like the Spreadsheet Tool for the Estimation of Pollutant Load (STEPL) (TetraTech, 2005) and PLOAD (CH2MHILL, 2001). The export coefficient approach is simple, but the variability in export coefficients 
for a given landuse is significant (Harmel et al., 2006). In these tools conservation practice effectiveness is derived from monitoring data taken from the literature and professional judgment. Conservation practices are also highly site specific (Djodjic et al., 2002; Gitau et al., 2004), and thus the application of measured data from dissimilar sites results in significant prediction uncertainty.

Phosphorus indices are another type of simple models used for conservation planning and to regulate the application of animal manure in the United States. A P Index is typically a tool that yields a categorical rating of $P$ loss from a single field. The categorical rating dictates allowable actions (or required conservation practices) by the landowner. P Indices are valuable tools to assess the potential risk for P leaving a site and traveling toward a water body (USNRCS, 1994), but they were not initially developed to be quantitative predictors of P loss (Lemunyon and Gilbert, 1993).

Quantitative approaches may be preferred due to increasingly common numeric water quality standards. The USEPA is actively encouraging the development of numeric nutrient standards for lakes and streams (USEPA, 2007c). Twenty-one states have developed or are engaged in the development of numeric nutrient criteria since 1997 (USEPA, 2007d). Process based models like the Soil and Water Assessment Tool (SWAT) (Arnold et al., 1998) can be used to identify management strategies which meet numeric water quality standards (Storm et al., 2006a,b). The SWAT model is commonly used to evaluate changes in pollutant load due to the establishment of conservation practices (Santhi et al., 2006; Bärlund et al., 2007; Arabi et al., 2008). Unfortunately, SWAT requires a great deal of specialized knowledge and data not readily available to conservation planners, and thus a simpler tool is needed (Veith et al., 2005).

There are no predefined accuracy standards for the evaluation of conservation practices by the USEPA. The accuracy of export coefficient models has not been rigorously evaluated as their primary purpose is planning and reporting. Due to their regulatory function, $P$ Indices have received more attention. Osmond et al. (2006) found substantial differences in $P$ Index ratings for a single field using $P$ Index procedures from different states, and expressed the need for a $\mathrm{P}$ management tool that can be applied uniformly across state boundaries. Process-based models like SWAT should better account for local conditions and be more broadly applicable.

The purpose of this research was to develop a tool which combines the ease of use associated with export coefficient approaches with the quantitative nature and site-specific applicability of a process based model. PPM Plus, is a simple user-friendly P loss prediction tool based on the SWAT model for use by conservation planners. This tool allows users with minimal training to predict runoff, sediment, and $P$ losses under a variety of management schemes and conservation practices throughout the State of Oklahoma. This tool is an expansion of the Pasture Phosphorus Management (PPM) Calculator (White et al., 2003a, 2009). PPM Calculator is a simplified SWAT model interface developed for pastures in the Lake Eucha/Spavinaw Basin (located in Northeastern Oklahoma and Northwestern Arkansas, USA). The accuracy of PPM Plus was assessed using a significant amount of field scale data across the southern United States.

\section{Model description}

\subsection{SWAT background}

SWAT is a basin-scale distributed hydrologic/water quality model used to evaluate stream flow and pollutant losses from mixed landuse basins. Distributed hydrologic models allow a basin to be broken into many smaller subbasins to incorporate spatial detail. SWAT also allows the optional subdivision of each subbasin into even smaller Hydrologic Response Units (HRU). SWAT operates on a daily time step, and long-term simulations can be performed using simulated or observed weather data. SWAT is a very robust and widely used hydrologic model; it is the product of 30 years of model development by the USDA-Agricultural Research Service and appears in more than 250 peer-reviewed published articles (Gassman et al., 2007). SWAT has been extensively used to evaluate the effects of conservation practices at the watershed scale (Bracmort et al., 2006; Parajuli et al., 2008), and has been applied successfully at field and plot scales (Anand et al., 2007; White et al., 2009).

The SWAT model was selected as the engine for PPM Plus due to its applicability at both the basin and field scales (Gassman et al., 2007). Data availability for calibration and validation are an important consideration in any modeling effort. Edges of field monitoring data are relatively rare as these data are quite expensive to collect. Monitoring data at the watershed scale, such as stream flow gages and water quality samples from streams and rivers, are far more plentiful. The use of a basin scale model allows the incorporation of these more plentiful data for the purposes of hydrologic and nutrient calibration and validation under differing conditions. In addition, the availability of these basin scale data may allow the development of regional calibration parameter sets. Although not a true calibration at the field scale, this approach should yield more accurate predictions compared to a SWAT model with default parameters.

\subsection{PPM Plus interface}

PPM Plus was designed to be easy to use, the interface isolates almost all the SWAT-related complexity from the user. For full documentation of PPM Plus refer to White (2007). PPM Plus is an input and output interpreter for a highly modified version of SWAT (based on build number 5.11.2007). The user interface is the only portion of the tool that the user sees; the SWAT model is completely hidden. The main form (Fig. 1) contains entries for record keeping, location, topographical characteristics, soil types, climate selection, soil test phosphorus (STP), field management operations, and Best Management Practices (BMP).

\subsection{Field management}

The management routines are flexible and allow the user to select from a number of common field operations. Available options in the interface change depending upon whether a pasture or a cultivated system is selected; only relevant management options are shown.

\subsubsection{Pasture management}

If pasture is selected the user must specify forage type, animal waste application history, and forage management. Optional nitrogen $(\mathrm{N})$ or P fertilization, animal manure application, grazing and forage removal selections are supported. Both rotational and continuous grazing with supplemental feed can be simulated. Grazing is halted or supplemental feed is provided automatically if the available forage declines below a grazing cutoff (BIOMIN) value measured in $\mathrm{kg}$ of dry forage per hectare. Parameters for the runoff sub-model, including Curve Number and Manning's $n$ for overland flow, vary with the user specified forage management (White, 2007). Five forage management levels are available:

- Under utilized, i.e., excellent forage stand during the growing season. Minimum dry forage is $2000 \mathrm{~kg} \mathrm{ha}^{-1}$, which is approximately $10-12 \mathrm{~cm}$ of fescue (Barnhart, 1998).

- Optimally managed for forage production with no significant overgrazing. Minimum dry forage is $1500 \mathrm{~kg} \mathrm{ha}^{-1}$ (7-10 cm of fescue), which is within the optimal range recommended by Bidwell and Woods (1996).

- Over-utilized due to excessive stocking. Short periods of overgrazing are allowed, but no visible signs of erosion. Minimum dry forage is $1200 \mathrm{~kg} \mathrm{ha}^{-1}$ (5-7 cm of fescue).

- Moderate overgrazing allowed during the growing season. Field has visible signs of erosion. Minimum dry forage is $800 \mathrm{~kg} \mathrm{ha}^{-1}$ (4-6 cm of fescue).

- Severe overgrazing allowed for a significant portion of the year. Field exhibits visible signs of erosion with active gullies and rills. Minimum dry forage is $500 \mathrm{~kg} \mathrm{ha}^{-1}$

\subsubsection{Cultivated field management}

The crop, and its typical planting and harvest dates must be specified. Available crops include small grains, grain sorghum, corn, cotton, peanuts, and soybeans. Irrigation and graze-out options are supported. One primary tillage type must be selected (conventional tillage, conservation tillage, or no-till). Contour farming and terracing options are available. Fertilization, grazing, and forage removal are optional.

\subsection{Available conservation practices}

\subsubsection{Ponds and wetlands}

The ponds represented in PPM Plus are intended to represent typical farms which intercept and trap sediment and nutrients, but are often intended for water supply. The fraction of the field draining to the pond is the only user input. Pond size 


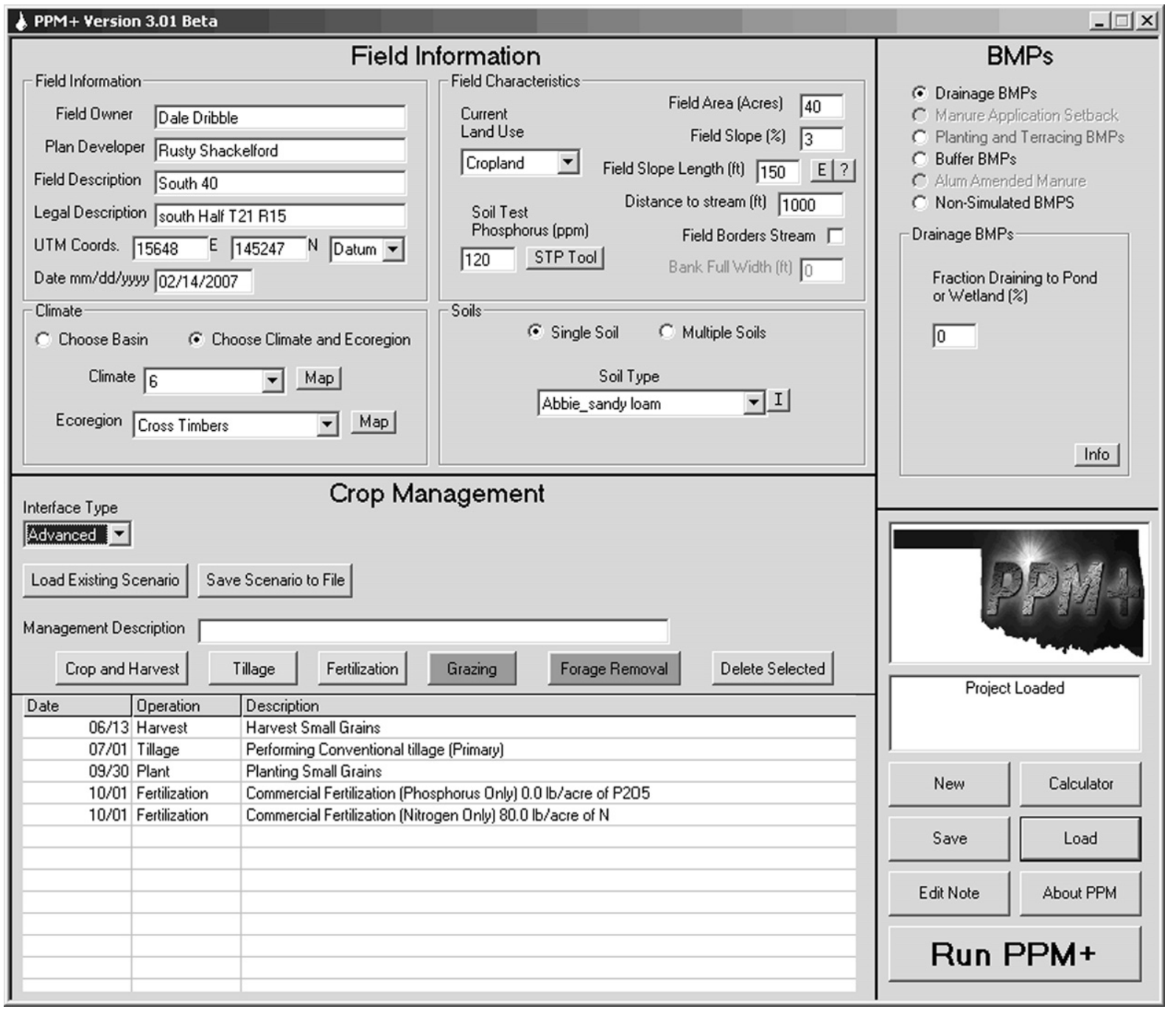

Fig. 1. PPM Plus main form.

is based on the location and recommended drainage area to surface area ratios provided by Whitis (2002). This ratio is 30:1 in western Oklahoma and 15:1 in the east to reflect different rainfall conditions. All ponds are assumed to be $1.5 \mathrm{~m}$ in depth, and all other pond parameters are defaults. Knight and Cooper (1990) measured $70 \%$ removal efficiency for $\mathrm{N}$ and $\mathrm{P}$ compounds in a 1.09 ha flood and sediment control structure. Tests with a similar structure in PPM Plus yielded a 69\% reduction in total P. Many small ponds in Oklahoma discharge only a small fraction of the water they receive in a typical year and have long detention times, thus high $\mathrm{P}$ trapping efficiency.

\subsubsection{Riparian and grass buffers}

Grass and riparian buffers trap sediment and nutrients in route to waterways. Buffers are a very effective conservation measure when properly placed, established and maintained. Buffer width and area are required inputs. The buffer area is removed from the area of the main field and simulated as grass and/or forested. The official SWAT model applies the same removal efficiency equation for sediment, soluble P, and particulate P based solely on the buffer width:

$T_{\mathrm{F}}=0.367 W_{F}^{0.2967}$

where $T_{\mathrm{F}}$ is fractional trapping efficiency and $W_{\mathrm{F}}$ is the filter strip width in meters. The modified SWAT model in PPM Plus was altered to treat soluble nutrients conservatively through buffers. Peterjohn and Correll (1984) found 85\% removal of total P, but no net loss of soluble P within a riparian buffer. Klapproth and Johnson (2000) presented a summary of existing literature on the removal mechanisms of $P$ in buffers. They concluded that the primary mechanism of $\mathrm{P}$ removal is sediment deposition.

Cattle exclusion from riparian areas is available as a conservation measure even though the effect is not directly simulated by SWAT. Unless cattle exclusion is specified, cattle are assumed to have unrestricted access to any stream adjacent to the field. The contribution of cattle is based on the estimated amount of manure deposition within the riparian zone. James et al. (2007) observed dairy cattle behavior including deposition of manure in and around streams. They found that $12 \%$ of cattle manure was deposited within $10 \mathrm{~m}$ of a stream, and $6 \%$ was deposited

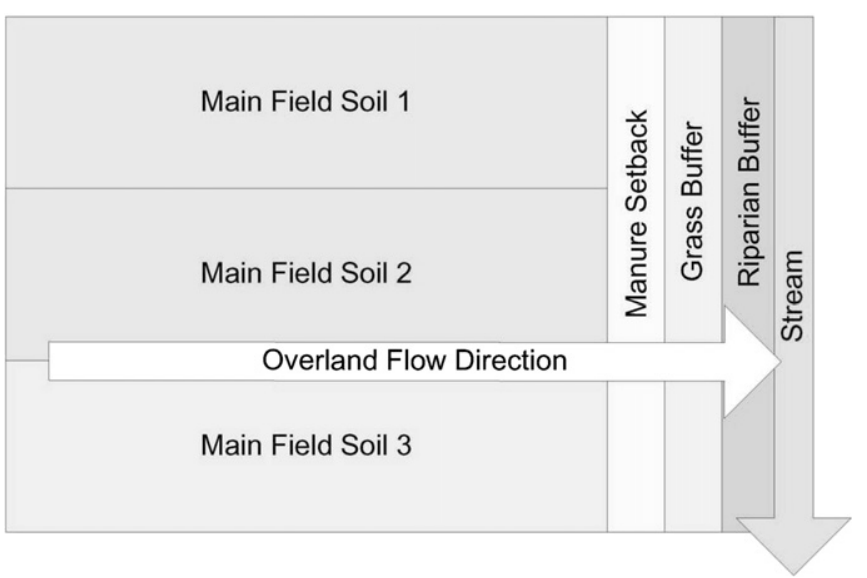

Fig. 2. SWAT Hydrologic Response Units (HRU) used in SWAT by PPM Plus. Includes optional HRU. 


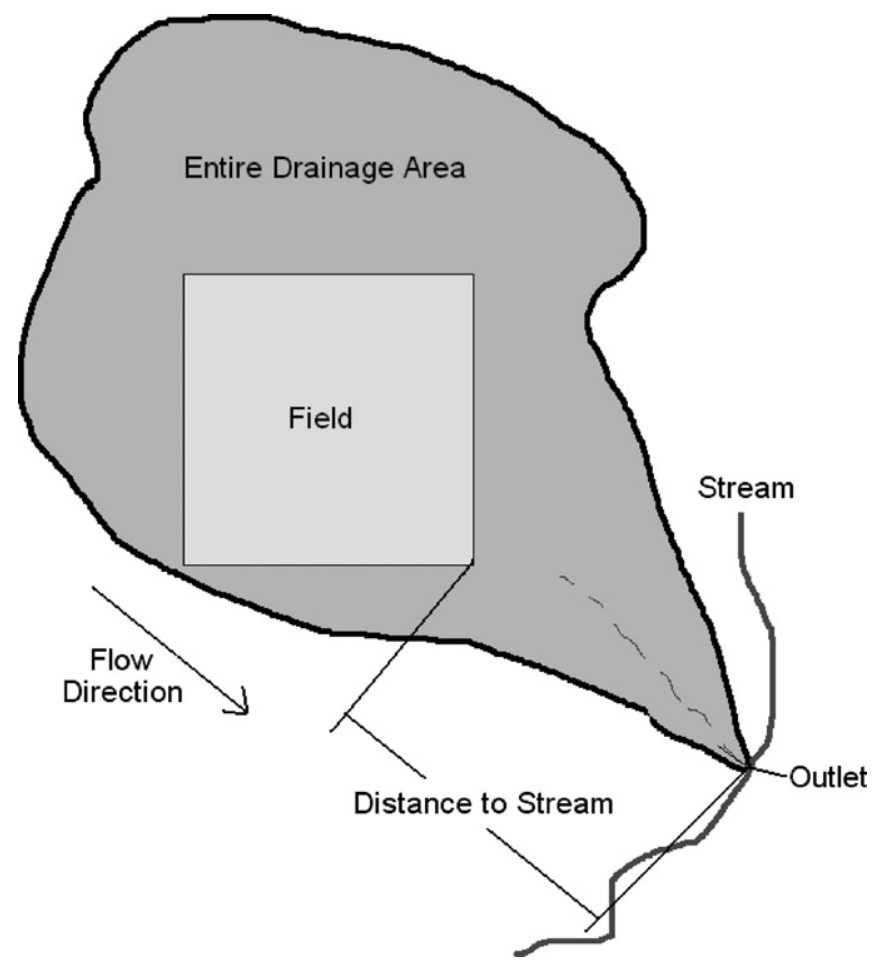

Fig. 3. Illustration representing a field within a larger subbasin area. The subbasin area is defined as the drainage area at the outlet.

directly into the water. These estimates are used to predict the fraction of all cattle manure deposited in or near the stream. Nutrients in manure deposited in the stream are considered direct additions to the total predicted nutrient load.

\subsection{Statewide database development}

Climate and soils databases were developed to properly represent conditions across the state of Oklahoma. Oklahoma has large differences in average rainfall, ranging from $380 \mathrm{~mm} \mathrm{yr}^{-1}$ to $1400 \mathrm{~mm} \mathrm{yr}^{-1}$. The state was divided into nine climate zones based on annual rainfall as estimated by the Parameter-elevation Regressions on Independent Slopes Model (Daly et al., 2001). Each county was assigned to a single climate zone; a National Weather Service weather station was selected within each area to represent the climate for the entire zone.

Geologic and rainfall diversity have produced a wide variety of soils across the state. Soils were derived from the State Soil Geographic (STATSGO) (USDA, 1991a) and Soil Survey Geographic (SSURGO) (USDA, 1991b) databases. SSURGO was the primary source for soil characteristics. SSURGO data were the most detailed digital soil data available for Oklahoma, but the database was incomplete. To cover soil series unavailable in SSURGO, STATSGO data were included. PPM Plus includes the Official Soil Series Description provided by the USNRCS (USNRCS, 2007) for each of the 3200 soil series in the database.

\subsection{Model Discretization}

PPM Plus makes predictions of sediment, runoff, and P delivered to the stream by using SWAT's subbasin scale components. PPM Plus is simple compared to typical SWAT model applications. It uses a SWAT model consisting of one subbasin and six HRU (Fig. 2). The majority of these HRU are optional depending upon conservation practice and soil configurations.

SWAT uses the Modified Universal Soil Loss Equation (MUSLE) (Williams, 1975) to predict sediment delivery. MUSLE was developed using small mixed landuse watershed data and implicitly includes a delivery ratio. MUSLE is sensitive to drainage area, and topographical characteristics such as flow length which influence peak flow. In PPM Plus the user must measure the distance from the field to the nearest stream from a 1:24,000 USGS topographic map to define the flow length.

Subbasin area is an important factor in SWAT sediment predictions (Bingner et al., 1997; White, 2001). Subbasin area is the contributing area where the delivered material meets the stream, not simply the area of the field. This point where flow from the field meets the stream is referred to as the "outlet" in SWAT (Fig. 3). An average subbasin size was defined for each climate zone based on a series of topographic analyses conducted within basins across Oklahoma. The National Hydrographic Dataset for 19 USGS 8-digit Hydrologic Units in various climate zones was analyzed to determine the average subbasin size that corresponded to the USGS $1: 24,000$ drainage network. Average subbasin area was larger in the more arid panhandle region. Tucker and Bras (1998) found a positive correlation between drainage density and rainfall. An analysis of variance procedure was used to determine which zones had significantly different mean areas. Tukey $95 \%$ simultaneous confidence intervals (Tukey, 1953) were developed for all pairwise comparisons by climate zone. There were no significant differences $(\alpha=0.05)$ among zones 3-9; only zones 1 and 2 were significantly different. The mean area derived from each significantly different climate zone group was used to set the subbasin area in PPM Plus.

\section{Current SWAT 2005}

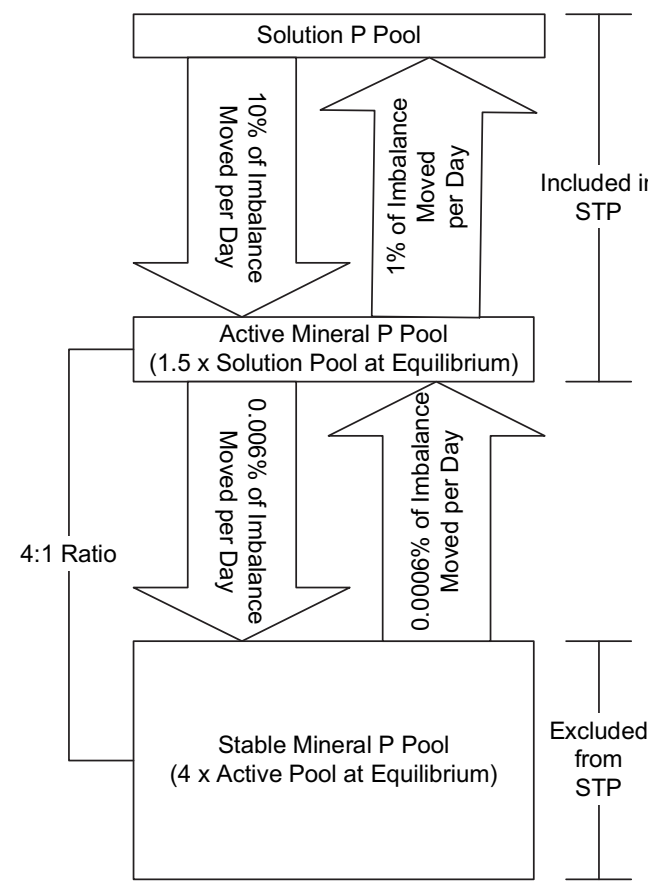

PPM Plus Version

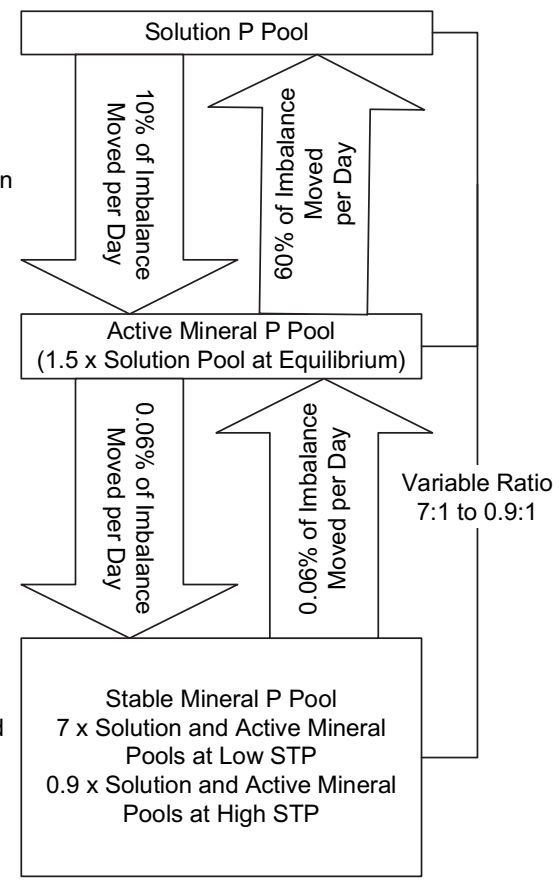

Fig. 4. Original SWAT P Model (left) and modified SWAT P Model used in PPM Plus (right). 


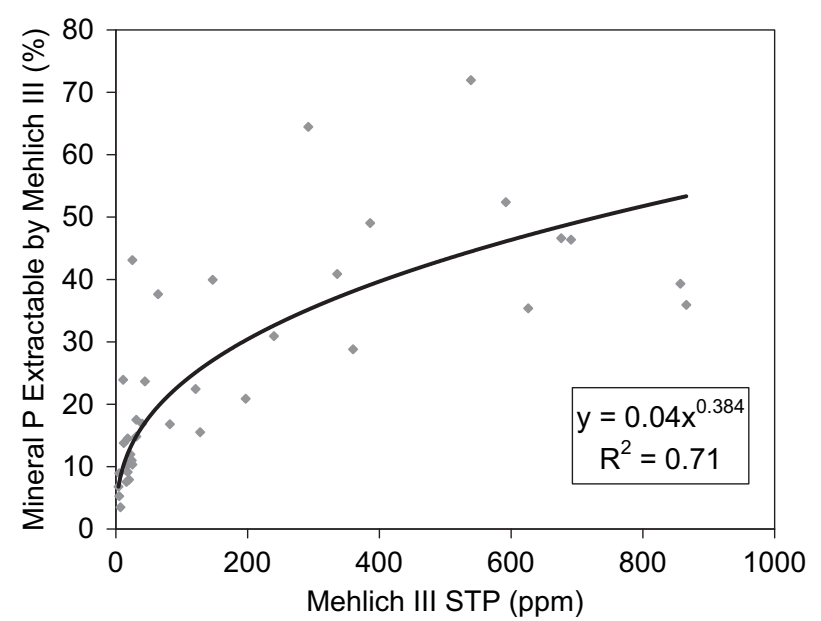

Fig. 5. Total mineral P extracted by Mehlich III as a function of soil test phosphorus (STP). Relationship developed from data presented by Sharpley et al. (2004).

\subsection{SWAT modifications}

The SWAT model used in PPM Plus includes a number of modifications to improve P predictions. These modifications focused on the soil P routines, to include recent research and an improved understanding of $\mathrm{P}$ cycling in soils. Special attention was directed to $\mathrm{P}$ enriched systems resulting from repeated animal manure application. These changes should be more important in pasture and other non-cultivated areas which are not subject to anthropogenic soil mixing. Only relatively simple modifications that were most relevant to PPM Plus applications were included. SWAT P predictions may be further improved through more complex modifications, but these were beyond the scope of this research.

\subsubsection{SWAT phosphorus model}

The SWAT P model is based on the concept of separate P pools within each soil layer (Fig. 4). SWAT partitions soil $\mathrm{P}$ into six pools; three intended to represent inorganic $\mathrm{P}$ forms and three for organic forms. These three inorganic P pools (Stable, Active and Solution) are in dynamic equilibrium. Transformations involving the organic pools (Stable, Active, and Fresh) are based on mineralization, decomposition, and immobilization equations and were not modified.

The three mineral pools (Stable, Active, and Solution) were the focus of the soil P modifications made to SWAT. It should be noted that there is considerable confusion by scientists and engineers as to what exact forms of $\mathrm{P}$ are in each pool, but the function and interactions between the pools are well defined in the SWAT model (Fig. 4). The Stable mineral pool represents stable insoluble P forms not readily available for plant uptake. The Stable mineral pool is in slow equilibrium with the Active pool, and by default is four times larger making it the largest of the mineral $P$ pools. The Active mineral pool interacts slowly with the Stable pool and quickly with the Solution pool. The Active pool represents $\mathrm{P}$ which is reversibly precipitated or adsorbed, but is less active than Solution P. By default this pool is 1.5 times larger than the Solution pool. The Solution pool includes soluble mineral P in the soil solution and sorbed $\mathrm{P}$ which can easily become soluble. Plant $\mathrm{P}$ uptake, soluble $\mathrm{P}$ in surface runoff and P leaching are taken from the Solution pool. P mineralized from organic matter and inorganic fertilizers contribute to it. The initial Solution pool value is a user input and sets both the Active and Stable P pool values via their respective equilibrium ratios.

\subsubsection{Redefining phosphorus pool equilibriums}

SWAT uses fixed ratios to define the equilibrium between the Solution, Active, and Stable mineral pools. The fixed ratio between the Active and Stable mineral $\mathrm{P}$ pools (currently 1:4) was modified to a dynamic coefficient based on Mehlich III STP. A relationship between Mehlich III STP and total mineral soil P was developed using data presented by Sharpley et al. (2004) (Fig. 5). These data indicated that as Mehlich III STP increased, the fraction of the total mineral $\mathrm{P}$ within the soil extracted increased nonlinearly. This implies that the amount of $P$ fertilizer required to raise Mehlich III STP by one unit is greater at lower values. These data contain a variety of soils with differing Mehlich III STP. Some have a long-term history of manure application. Pautler and Sims (2000) also found a nonlinear relationship between total P and Mehlich I STP. Allen (2004) found the relative proportion of extractable P to total soil $\mathrm{P}$ to be slightly greater with higher $\mathrm{P}$ application rates. Whalen and Chang (2001) observed an Olson extractable P to total P ratio of 0.13 in plots with no manure application and a ratio of 0.27 in a soil with long term additions of manure. A preponderance of the literature indicates that the extractability of $P$ changes with increased soil P content, and that a dynamic coefficient between the stable and active pools is warranted.

The extractability relationship (Fig. 5) was used to make Mehlich III STP a direct SWAT input. The Mehlich III STP extractable fraction was assumed to be the sum of the Soluble and Active mineral P pools and neglected any Mehlich III extractable organic $\mathrm{P}$, which may be significant in some high organic soils. The existing equilibrium between the Stable and Active pools was modified to a dynamic equilibrium between the Stable pool and the sum of Active and Solution pools. The new equilibrium ratio varied between 7.0 at low Mehlich III STP to 0.9 at higher values. This dynamic ratio was developed empirically using measured soil data given in Sharpley et al. (2004). The modified and original mineral P models are given in Fig. 4.

\subsubsection{Rate of phosphorus transformation}

SWAT uses fixed rate constants to redistribute $P$ imbalances between the Solution, Active, and Stable P pools. Ten percent (0.10) of the imbalance between the Solution and the Active pools is moved daily when the imbalance favors movement from Solution to Active (sorption). One percent (0.01) is moved if the imbalance favors movement from Active to Solution (desorption). Vadas et al. (2006) developed coefficients ( 0.10 for sorption, 0.60 for desorption) which improved EPIC model predictions; these were incorporated into the modified SWAT model.

$P$ transfer coefficients between the Active and Stable P pools were also increased. SWAT transfers a relatively small fraction of the imbalance between the Active and Stable pools each day ( $0.006 \%$ or $0.0006 \%$, depending upon direction). Only about $90 \%$ of excess $P$ in the Active pool is moved to the Stable pool in four years. These rate constants were based on Jones et al. (1984) and Cox et al. (1981), who used the decline in STP following fertilization over several years at the plot scale. It is difficult to separate the effects of P stabilization (indicated by reduced STP) to less available forms from other complicating factors. A net loss of P from crop uptake and runoff losses will also result in reduced STP over time, making it very difficult to isolate any single process with plot scale experiments.

Soil incubation studies may allow better isolation of individual effects. Laboski and Lamb (2003) measured Bray I STP in soils incubated for nine months after receiving manure and inorganic $P$ for eight soils. Extractability changed significantly only during the first month after application for a majority of the soils. They observed a relatively small $(<3 \%)$ decrease in adjusted Bray I STP after inorganic P fertilization between months one and nine. Ebeling et al. (2003) incubated a silt loam receiving various $P$ application rates for 64 weeks. They concluded that Bray-Kurtz and Mehlich III extractable phosphorus were not affected by incubation time except at very high rates. Koopmans et al. (2004) found strong indications that the total pool of stable sorbed $\mathrm{P}$ (sum of reversibly adsorbed $\mathrm{P}$ and quasi-irreversibly

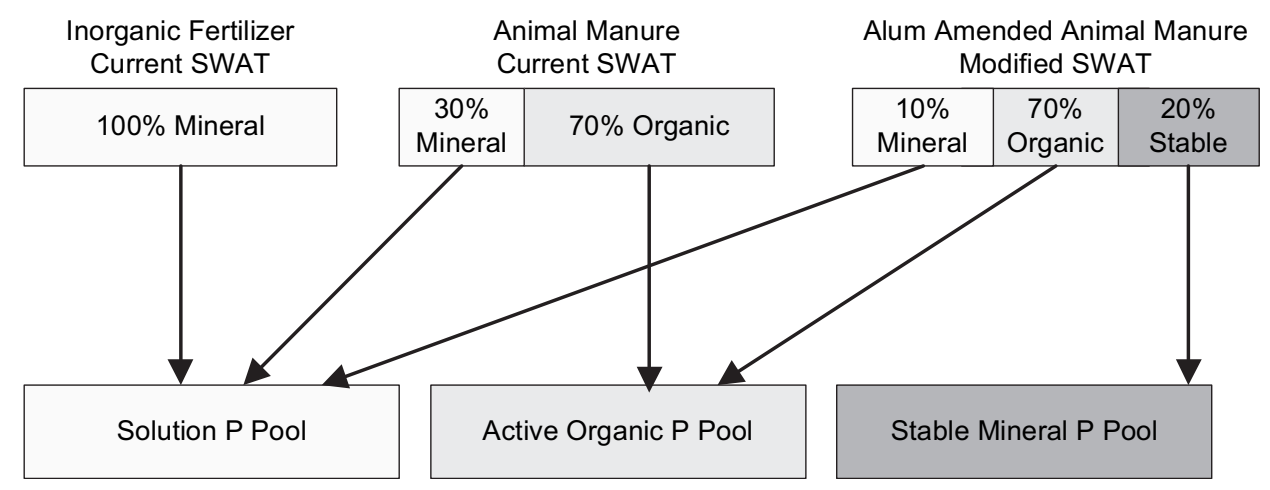

Fig. 6. Current and modified SWAT phosphorus (P) routines for PPM Plus. 
Table 1

Eleven Oklahoma basins used in the development of state-wide hydrologic SWAT calibration for use in PPM Plus.

\begin{tabular}{|c|c|c|c|}
\hline USGS gage name & Primary ecoregion & Drainage area $\left(\mathrm{km}^{2}\right)$ & Period of record $(\mathrm{yr})$ \\
\hline Skeleton Creek near Lovell, OK & Central Great Plains & 1058 & 38 \\
\hline Sand Creek at Okesa, OK & Cross Timbers & 359 & 33 \\
\hline Big Cabin Creek near Big Cabin, OK & Central Irregular Plains & 1161 & 51 \\
\hline Spavinaw Creek near Sycamore, OK & Ozark Highlands & 343 & 44 \\
\hline Illinois River near Tahlequah, OK & Ozark Highlands & 2474 & 51 \\
\hline Gaines Creek near Krebs, OK & Arkansas Valley & 1517 & 8 \\
\hline Fourche Maline near Red Oak, OK & Arkansas Valley & 315 & 51 \\
\hline Lee Creek near Short, OK & Boston Mountains & 1084 & 51 \\
\hline Blue Beaver Creek near Cache, OK & Central Great Plains & 63 & 38 \\
\hline Cobb Creek near Eakly, OK & Central Great Plains & 341 & 37 \\
\hline Mountain Fork at Smithville, OK & Ouachita Mountains & 826 & 14 \\
\hline Average & - & 867 & 38 \\
\hline
\end{tabular}
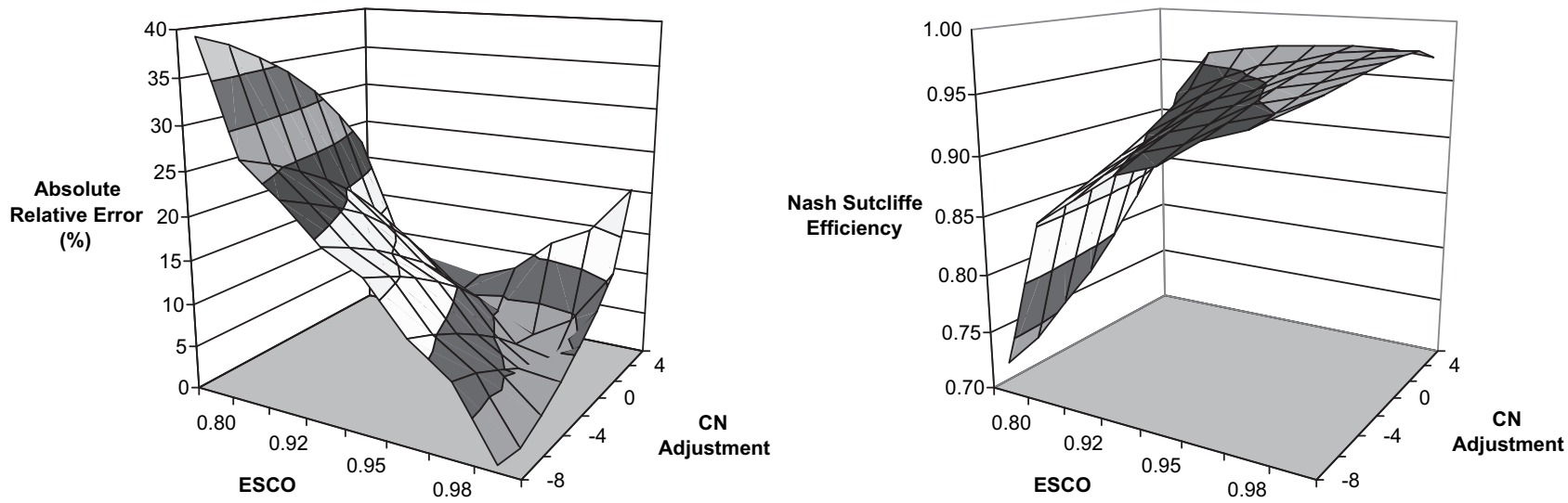

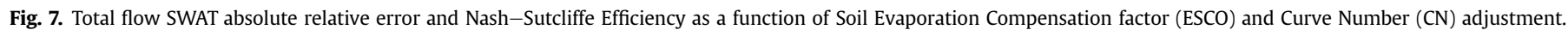

bound $\mathrm{P}$ ) to be close to equilibrium with the faster reacting $\mathrm{P}$ in a long term $\mathrm{P}$ uptake study on noncalcareous soils, indicating rapid P stabilization reactions. These studies suggest that the transfer between the active and stable pools to regain equilibrium may be faster than what the current SWAT routines allow. Clearly, soil mineralogy is important, but these data are not readily available for most soils. Little data were available to gage the appropriate value for the Active/Stable transfer coefficients. Therefore, these coefficients were increased by one order of magnitude in the modified SWAT model to increase the rate of P stabilization in SWAT and better reflect observations from soil incubation studies.

\subsubsection{Predicted Mehlich III STP change}

The SWAT model was modified to output an average annual HRU level P balance accounting for fertilizer and manure additions, losses in runoff, crop harvest, $\mathrm{P}$ in growing biomass and residue, and $\mathrm{P}$ in each soil layer. The net $\mathrm{P}$ balance, along with the relationship between soil total P and STP from Fig. 5, allows PPM Plus to estimate the annual change in Mehlich III STP resulting from any scenario simulated. The rate of Mehlich III STP increase is valuable for planning future manure applications and identifying long term sustainable management.

\subsubsection{Nutrient stabilized manures}

The addition of aluminum (e.g. aluminum sulfate or alum), iron, or calcium containing amendments to animal manures has been shown to reduce the solubility of P (Moore et al., 1999). The addition of alum to poultry litter reduces soluble P concentration in runoff when applied to agricultural fields (Moore et al., 1999, 2000; Sims and Luka-McCafferty, 2002). In an effort to account for reduced P solubility in treated manures, the SWAT model was modified to allow the addition of stable $P$ forms in animal manure, which do not directly influence soluble $P$ in surface runoff.

In SWAT, animal manures are composed of relatively soluble mineral and readily degradable organic forms of P. These are directed to the Solution and Fresh Organic pools upon application (Fig. 6). The addition of alum has been shown to reduce water soluble $\mathrm{P}$ in manures by $66 \%$ in farm scale data collected by Sims and LukaMcCafferty (2002). In an effort to better represent the reduced P solubility in alum treated manure, the SWAT model was modified to allow a fraction of applied $\mathrm{P}$ to be routed directly to the Stable P pool. In PPM Plus alum amended manures have $66 \%$ of the mineral fraction directed to the stable mineral pool, where it is not directly available for loss as soluble P. The application of alum reduced soluble P losses attributable to manure application in PPM Plus by $50 \%-70 \%$ during testing.

\subsection{Hydrologic calibration}

Calibration with measured data generally improves model predictions. The purpose of calibration is to refine relatively uncertain model parameters to better represent local conditions. PPM Plus uses calibration parameters for the hydrologic functions which were derived from 11 SWAT models of basins across Oklahoma. SWAT predictions were compared to observed USGS stream flow records to develop a single set of calibration parameters applicable to the entire State (Table 1).

\subsubsection{Calibration model development}

Eleven basins were selected based on the availability of USGS daily stream flow records from 1955 to 2005. Due to the size of the basins, model discretization was coarse compared to other SWAT models developed in Oklahoma (Storm et al., 2001, 2003, 2006a,b). Model discretization can have a significant effect on sediment and nutrients, but has little impact on runoff volume (Bingner et al., 1997; White, 2001; Jha et al., 2004). These SWAT models were constructed using a USGS 30 m resolution Digital Elevation Model, National Hydrography Dataset streams, STATSGO soils, 1992

Table 2

SWAT highest performing combinations of Soil Evaporation Compensation factor (ESCO) and Curve Number (CN) during model calibration. Values selected for fina calibration are italicized.

\begin{tabular}{lcll}
\hline $\begin{array}{l}\text { Soil evaporation } \\
\text { compensation factor }\end{array}$ & $\begin{array}{l}\text { Curve number } \\
\text { adjustment }\end{array}$ & $\begin{array}{l}\text { Relative } \\
\text { error }\end{array}$ & $\begin{array}{l}\text { Nash-Sutcliffe } \\
\text { Efficiency }\end{array}$ \\
\hline 0.90 & 8.0 & $0 \%$ & 0.96 \\
0.92 & 8.0 & $-3 \%$ & 0.97 \\
0.97 & 2.0 & $2 \%$ & 0.97 \\
0.97 & 4.0 & $-1 \%$ & 0.97 \\
0.98 & 0.0 & $1 \%$ & 0.97 \\
0.98 & 2.0 & $-1 \%$ & 0.97 \\
1.0 & -8.0 & $1 \%$ & 0.96 \\
1.0 & -6.0 & $0 \%$ & 0.97 \\
1.0 & -4.0 & $-2 \%$ & 0.97 \\
1.0 & -2.0 & $-3 \%$ & 0.97 \\
\hline
\end{tabular}



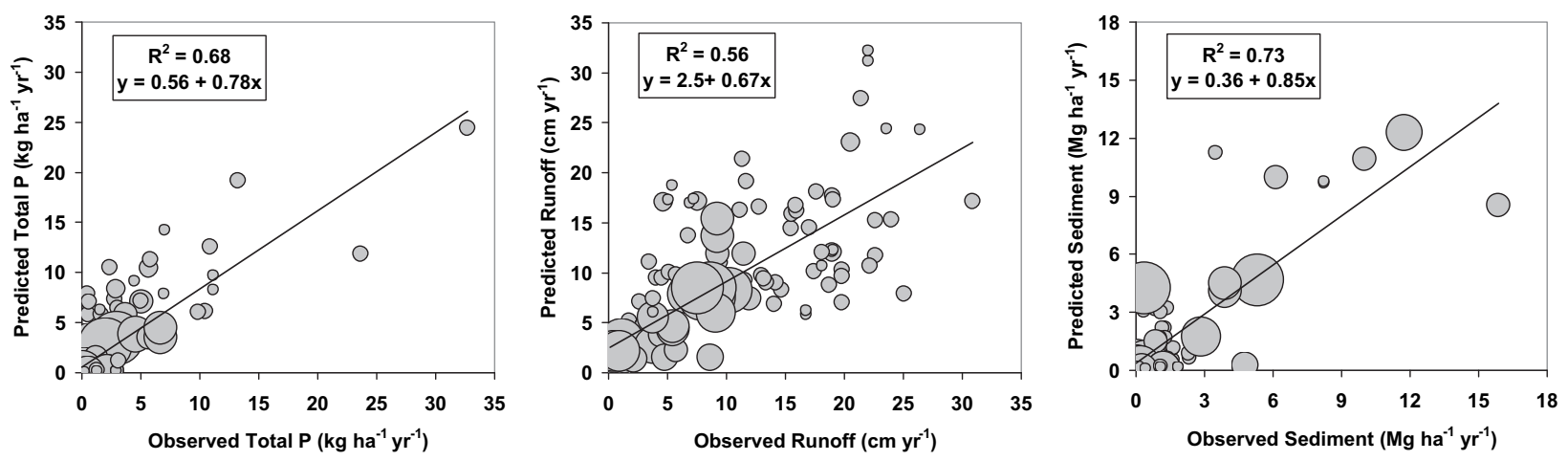

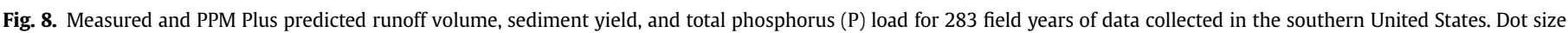
reflects monitoring duration at each site.

National Land Cover Data, and National Weather Service observed daily precipitation and temperature. Management for each basin was derived from previous SWAT modeling projects and professional judgment (White et al., 2003b; Storm et al., 2005, 2006a,b). Management was held constant across ecoregions, but varied generally from west to east with changing precipitation.

\subsubsection{Multi-model calibration}

Two of the most sensitive SWAT parameters, Soil Evaporation Compensation factor (ESCO) and Curve Number (CN), were adjusted to obtain the best fit in stream flow for all 11 basins simultaneously. Eight levels of $\operatorname{ESCO}(0.8,0.9,0.92,0.94,0.95$, $0.97,0.98$, and 1.0$)$ and eight levels of $\mathrm{CN}$ adjustment $(-8,-6,-4,-2,0,2,4$, and 8$)$ were explored in full factorial. A total of 64 combinations were evaluated on each of the 11 SWAT models. Each combination was evaluated using relative error and Nash-Sutcliffe Efficiency (Nash and Sutcliffe, 1970) for observed and predicted average annual stream flow. Fig. 7 illustrates how model performance changed over the range of ESCO and CN adjustments explored. There were several combinations of ESCO and CN adjustment which resulted in good model performance (Table 2). Of these, $\mathrm{ESCO}=0.98$ and $\mathrm{CN}$ adjustment $=0$ was selected due in part to close proximity to SWAT default values ( $\mathrm{ESCO}=0.95$ and $\mathrm{CN}$ adjustment $=0$ ). Monthly observed and predicted surface runoff and total flow were also examined and found to be acceptable.

\section{Results}

\subsection{Field scale validation}

PPM Plus was validated at the field scale using measured data collected under natural rainfall from 63 different monitored field sites. A total of 286 field years of data were included from sites in Oklahoma, Arkansas, Texas, and Georgia. These monitored fields range in size from 0.5 to 18.4 ha. The majority of these data were derived from published sources. The Measured Annual Nutrient loads from AGricultural Environments (MANAGE) Database (Harmel et al., 2006) were used to identify relevant publications. Studies including the application of animal wastes were preferentially selected. Additional data were collected specifically for the validation of PPM Plus. Six pastures in eastern Oklahoma were instrumented and monitored under a variety of cattle stocking rates and poultry litter applications.

The validation dataset is very diverse, rainfall ranged from 620 to $1390 \mathrm{~mm} \mathrm{yr}^{-1}$, STP varied from 5 to $360 \mathrm{mg} \mathrm{kg}^{-1}$, with P fertilization rates up to $350 \mathrm{~kg} \mathrm{ha}^{-1} \mathrm{yr}^{-1}$. The 63 combined datasets showed little correlation with any single causal factor (White, 2007). This article deals primarily with the development of PPM Plus. Full description of the validation dataset and results are given by White (2007).

Comparisons between PPM Plus predicted and measured data are given in Fig. 8. The model adequately simulated surface runoff volume at the field scale $\left(R^{2}=0.56\right)$, especially given that many simulations utilized rainfall data which were collected at a significant distance from the monitored fields. Overall there was an under prediction at higher annual runoff volumes (slope $=0.67$ ). The model performed well in the prediction of sediment yield $\left(R^{2}=0.73\right.$; slope $\left.=0.85\right)$. PPM Plus validated well for total P yield, especially considering the lack of field scale calibration and diversity of field data included $\left(R^{2}=0.66\right.$; slope $\left.=0.78\right)$. Observed total $\mathrm{P}$ loads ranged from 0.01 to $35 \mathrm{~kg} \mathrm{ha}^{-1} \mathrm{yr}^{-1}$ with an average of $2.3 \mathrm{~kg} \mathrm{ha}^{-1} \mathrm{yr}^{-1}$. The range in measured losses reflects the wide range in management, particularly $\mathrm{P}$ application rates in the validation dataset.

\section{Conclusions}

The primary objective of this research was to put the predictive capacity of one of the most widely used hydrologic/water quality models into the hands of people who make farm management decisions which impact water quality. These decisions are often made with little or no knowledge of their true offsite water quality impacts. As numeric water quality standards become more common, the need for quantitative assessment of nutrient losses will increase. The use of more process-based models should allow more accurate assessment of P loss under a wider range of conditions than the current export coefficient based approaches.

Models like SWAT are constantly evolving and improve every year. Shortcomings in the routines of current models can be quickly overcome. The P routines in SWAT were modified for use in PPM Plus, but additional improvements are always needed. SWAT is not entirely physically based, processes are lumped and simplifications are made. It may be difficult to individually evaluate each model component modified in this research, but overall the model performed very well given the diversity of the validation dataset. These models are sufficiently accurate for the purposes of this research, and will continue to improve with our ever-increasing knowledge of natural systems.

Large expenditure of taxpayer resources has fueled a need for quantitative evaluation of water quality program benefits. The development of PPM Plus demonstrates that a complex hydrologic/ water quality model can be used to power an easy to use, quantitative nutrient management and conservation practice evaluation tool. PPM Plus is currently being used in Oklahoma to evaluate conservation practices subsidized via USEPA 319 programs. The development of a similar tool for the State of Texas is underway. The Texas Best management practice Evaluation Tool (TBET) will be used to predict the effects of both USEPA and state conservation programs across the state. In the future, this approach may be applicable to regional or national conservation program evaluation and optimization. 


\section{Acknowledgements}

We thank the Oklahoma Conservation Commission, the U.S. Environmental Protection Agency Region VI, and the Oklahoma State University Division of Agricultural Sciences and Natural Resources Agricultural Experiment Station for funding this work.

\section{References}

Allen, B.L., 2004. Soil and runoff phosphorus as affected by fertilizer and manure application. PhD Dissertation. Iowa State University, Ames, IA.

Anand, S., Mankin, K.R., McVay, K.A., Janssen, K.A., Barnes, P.L., Pierzynski, G.M., 2007. Calibration and validation of ADAPT and SWAT for field-scale runoff prediction. Journal of the American Water Resources Association 43, 899-910.

Arabi, M., Frankenberger, J.R., Engel, B.A., Arnold, J.G., 2008. Representation of agricultural conservation practices with SWAT. Hydrological Processes 22 (16), 3042-3055

Arnold, J.G., Srinivasan, R., Muttiah, R.S., Williams, J.R., 1998. Large area hydrologic model development and assessment part 1: model development. Journal of American Water Resources Association 34 (1), 73-89.

Bärlund, I., Kirkkala, T., Malve, O., Kämäri, J., 2007. Assessing SWAT model performance in the evaluation of management actions for the implementation of the Water Framework Directive in a Finnish catchment. Environmental Modelling and Software 22 (5), 719-724.

Barnhart, S., 1998. Estimating Available Pasture Forage. Iowa State University, Ames, IA. Available at: <http://www.extension.iastate.edu/Publications/PM1758.pdf > (accessed 10.3.08).

Bidwell, T., Woods, B., 1996. Management Strategies for Rangeland and Introduced Pastures. Oklahoma State University, Stillwater, OK. Available at: <http:// okrangelandswest.okstate.edu/pdfFiles/OSUextPubs/F-2869.pdf $>$ (accessed10.3.08).

Bingner, R.L., Garbrecht, J., Arnold, J.G., Srinivasan, R., 1997. Effect of watershed subdivision on simulation runoff and fine sediment yield. Transactions of the ASABE 40 (5), 1329-1335.

Bracmort, K.S., Arabi, M., Frankenberger, J.R., Engel, B.A., Arnold, J.G., 2006. Modeling long-term water quality impacts of structural BMPs. Transactions of the ASABE 49 (2), 367-374.

CH2MHILL, 2001. PLOAD version 3.0. An ArcView GIS tool to calculate nonpoint sources of pollution in watershed and stormwater projects. Availability at: <http:// permanent.access.gpo.gov/lps49376/PLOAD_v3.pdf > (accessed 10.14.09).

Cox, F., Kamprath, E., McCollum, R., 1981. A descriptive model of soil test nutrient levels following fertilization. Soil Science Society of America Journal 45, 529-532.

Daly, C., Taylor, G.H., Gibson, W.P., Parzybok, T.W., Johnson, G.L., Pasteris, P.A., 2001 High-quality spatial climate data sets for the United States and beyond. Transactions of the ASABE 43 (6), 1957-1962.

Djodjic, F., Montas, H., Shirmohammadi, A., Bergstrom, L., Ulen, B., 2002. A decision support system for phosphorus management at a watershed scale. Journal of Environmental Quality 31, 937-945.

Ebeling, A.M., Cooperband, L.R., Bundy, L.G., 2003. Phosphorus source effects on soil test phosphorus and forms of phosphorus in soil. Communications in Soil Science and Plant Analysis 34 (13), 1897-1917.

Gassman, P.W., Reyes, M.R., Green, C.H., Arnold, J.G., 2007. The Soil and Water Assessment Tool: historical development, applications and future research directions. Transactions of the ASABE 50 (4), 1211-1250.

Gitau, M.W., Veith, T.L., Gburek, W.J., 2004. Farm-level optimization of BMP placement for cost-effective pollution reduction. Transactions of the ASAE 47, 1923-1931.

Hardy, S.D., Koontz, T.M., 2008. Reducing nonpoint source pollution through collaboration: policies and programs across the U.S. States. Environmental Management 41, 301-310

Harmel, D., Potter, K., Ellis, P., Reckhow, K., Green, C., 2006. Compilation of measured nutrient load data for agricultural land uses in the United States. Journal of American Water Resources Association 42 (5), 1163-1178.

James, E., Kleinman, P., Veith, T., Stedman, R., Sharpley, A., 2007. Phosphorus contributions from pastured dairy cattle to streams. Journal of Soil and Water Conservation 62 (1), 40-47.

Jha, M., Gassman, P.W., Secchi, S., Gu, R., Arnold, J., 2004. Effect of watershed subdivision on SWAT flow, sediment, and nutrient predictions. Journal of American Water Resources Association 40 (3), 811-825.

Jones, C., Cole, C., Sharpley, A., Williams, J., 1984. A simplified soil and plant phosphorus model: I. Documentation. Soil Science Society of America Journal 48, 800-805.

Klapproth, J.C., Johnson, J.E., 2000. Understanding the Science Behind Riparian Forest Buffers: Effects on Water Quality. Virginia Tech, Blacksburg, VA. Available at: $<$ http://www.ext.vt.edu/pubs/forestry/420-151/420-151.html $>$ (accessed 10.3.8).

Knight, S., Cooper, C., 1990. Nutrient trapping efficiency of a small sediment detention reservoir. Agricultural Water Management 18 (2), 149-158.

Koopmans, G.F., Chardon, W.J., Ehlert, P.A.I., Dolfing, J., Suurs, R.A.A., Oenema, O., van Riemsdijk, W.H., 2004. Phosphorus availability for plant uptake in a phosphorus-enriched noncalcareous sandy soil. Journal of Environmental Quality 33 (3), 965-975.
Laboski, C., Lamb, J.A., 2003. Changes in soil test phosphorus concentration after application of manure or fertilizer. Soil Science Society of America Journal 67 (2), 544-554.

Lemunyon, J.L., Gilbert, R.G., 1993. The concept and need for a phosphorus assessment tool. Journal of Production Agriculture 6 (44), 483-486.

Moore, P.A., Daniel, T.C., Edwards, D.R., 1999. Reducing phosphorus runoff and improving poultry production with alum. Poultry Science 78 (5), 692-698.

Moore, P.A., Daniel, T.C., Edwards, D.R., 2000. Reducing phosphorus runoff and inhibiting ammonia loss from poultry manure with aluminum sulfate. Journal of Environmental Quality 29, 37-49.

Nash, J.E., Sutcliffe, J.V., 1970. River flow forecasting through conceptual models part I- a discussion of principles. Journal of Hydrology 10 (3), 282-290.

Osmond, D.L., Cabrera, M., Feagley, S., Hardy, G., Mitchell, C., Mylavarapu, R. Moore, P., Oldham, L., Thom, B., Stevens, J., Walker, F., Zhang, H., 2006. Comparing P-Indices for the Southern Region. Journal of Soil and Water Conservation 61, 325-337.

Parajuli, P.B., Mankin, K.R., Barnes, P.L., 2008. Applicability of targeting vegetative filter strips to abate fecal bacteria and sediment yield using SWAT. Agricultura Water Management 95, 1189-1200.

Pautler, M.C., Sims, J.T., 2000. Relationships between soil test phosphorus, soluble phosphorus, and phosphorus saturation in Delaware soils. Soil Science Society of America Journal 64 (2), 765-773.

Peterjohn, W.T., Correll, D.L., 1984. Nutrient dynamics in an agricultural watershed: observations on the role of a riparian forest. Ecology 65 (5), 1466-1475.

Radcliffe, D.E., Freer, J., Schoumans, O., 2009. Diffuse phosphorus models in the United States and Europe: their usages, scales, and uncertainties. Journal of Environmental Quality 38, 1956-1967.

Santhi, C., Srinivasan, R., Arnold, J.G., Williams, J.R., 2006. A modeling approach to evaluate the impacts of water quality management plans implemented in a watershed in Texas. Environmental Modelling and Software 21 (8), 1141-1157.

Schindler, D., 1978. Factors regulating phytoplankton production and standing crop in the world's freshwaters. Limnology and Oceanography 23 (3), 478-486.

Sharpley, A.N., McDowell, R.W., Kleinman, P.J.A., 2004. Amounts, forms, and solubility of phosphorus in soils receiving manure. Soil Science Society of America Journal 68 (6), 2048-2057.

Sims, J.T., Luka-McCafferty, N.J., 2002. On-farm evaluation of aluminum sulfate (alum) as a poultry litter amendment: effects on litter properties. Journal of Environmental Quality 31, 2066-2073.

Storm, D.E., Busteed, P.R., White, M.J., 2006a. Fort Cobb Basin - Modeling and Land Cover Classification. Oklahoma State University, Stillwater, OK. Available at: $<$ https://www.deq.state.ok.us/WQDnew/tmdl/fort_cobb/osu_fort_cobb_mode ling_jan_2006.pdf $>$ (accessed 10.03.08).

Storm, D.E., White, M.J., Smolen, M.D., Zhang, H., 2001. Modeling Phosphorous Loading for the Lake Eucha Basin. Oklahoma State University, Stillwater, OK. Available at: <http://biosystems.okstate.edu/home/dstorm/eucha/modeling/ OSU_EuchaReport_110101.pdf $>$ (accessed 10.03.08).

Storm, D.E., White, M.J., Stoodley, S., 2003. Stillwater Creek Modeling and Land Cover Classification. Oklahoma State University, Stillwater, OK. Available at $<$ http://biosystems.okstate.edu/home/dstorm/reports/Stillwater\%20Creek\%20 Draft\%20Composite\%203-31-03__.pdf> (accessed 10.03.08).

Storm, D.E., White, M.J., Armstrong, M.B., Christianson, L.E., Busteed, P.R., 2005. Targeting High Non-point Source Contributing Areas in the Turkey Creek Basin. Oklahoma State University, Stillwater, OK. Available at: <http://biosystems. okstate.edu/home/dstorm/reports/Turkey\%20Creek\%2012-1-2005\%20DRAFT. pdf $>$ (accessed 10.03.08)

Storm, D.E., White, M.J., Smolen, M.D., 2006b. Illinois River Upland and In-stream Phosphorus Modeling: Final Report. Oklahoma State University, Stillwater, OK. Available at: <http://www.crossroads.odl.state.ok.us/cgi-bin/showfile.exe?CISO ROOT $=/$ stgovpub\&CISOPTR $=562>$ (accessed 10.03.08).

TetraTech, 2005. User's guide: spreadsheet tool for the estimation of pollutant load (STEPL). U.S. Environmental Protection Agency. Available at: $<$ http://it.tetratechfx.com/stepl/STEPLmain_files/STEPLGuide310.pdf > (accessed 03.18.09).

Tucker, G., Bras, R., 1998. Hillslope processes, drainage density, and landscape morphology. Water Resources Research 34, 2751-2764.

Tukey, J., 1953. The problem of multiple comparisons. Unpublished notes. In: The Collected Works of John W. Tukey VIII: Multiple Comparisons. Chapman and Hall, New York, pp. 1948-1983.

USDA, 1991a. Soil Survey Geographic (SSURGO) Database: Data Use Information. Misc. Pub. 1527. U.S. Department of Agriculture, Washington, DC.

USDA, 1991b. State Soil Geographic (STATSGO) Database: Data Use Information. Misc. Pub. 1492. U.S. Department of Agriculture, Washington, DC.

USEPA, 2007a. National Water Quality Inventory: Report to Congress, 2002 Reporting Cycle. Doc. 841-R-07-001. U.S. Environmental Protection Agency, Washington, DC.

USEPA, 2007b. Clean Water Act Section 319(h) Grant Funds History. U.S. Environmental Protection Agency, Washington, D.C. Available at: <http://www.epa. gov/owow/nps/319hhistory.html > (accessed 10.14.09)

USEPA, 2007c. Nutrient Pollution and Numeric Water Quality Standards Memo. U.S Environmental Protection Agency, Washington, D.C. Available at: $<$ http://www.epa. gov/waterscience/criteria/nutrient/files/policy20070525.pdf $>$ (accessed 10.03.08).

USEPA, 2007d. Current Status: National Nutrient Strategy, vol. 2008. U.S. Environmental Protection Agency, Washington, D.C. Current Status of States \& Territories Numeric Nutrient Criteria for Class of Waters. Available at: <http:// www.epa.gov/waterscience/criteria/nutrient/strategy/status.html> (accessed 10.03.08). 
USNRCS, 1994. The Phosphorus Index: a Phosphorus Assessment Tool. United States Department of Agriculture, Natural Resources Conservation Service, Washington D.C. Available at: <http://www.nrcs.usda.gov/TECHNICAL/ECS/nutrient/ pindex.html $>$ (accessed 10.03.08).

USNRCS, 2007. Official Soil Series Descriptions. United States Department of Agriculture, Natural Resources Conservation Service. Available at: <http://soils. usda.gov/technical/classification/osd/index.html > (accessed 10.03.08).

Vadas, P.A., Krogstad, T., Sharpley, A.N., 2006. Modeling phosphorus transfer between labile and nonlabile soil pools: updating the EPIC model. Soil Science Society of America Journal 70 (3), 36-743.

Veith, T., Sharpley, A., Weld, J., Gburek, W., 2005. Comparison of measured and simulated phosphorus losses with indexed site vulnerability. Transactions of the ASABE 48 (2), 557-565.

Whalen, J.K., Chang, C., 2001. Phosphorus accumulation in cultivated soils from long-term annual applications of cattle feedlot manure. Journal of Environmental Quality 30 (1), 229-237.

White, M.J., 2001. Evaluation of Management Practices and Examination of Spatial Detail Effects Using the SWAT Model. MS thesis. Oklahoma State University, Stillwater, OK.
White, M.J., Storm, D.E., Demissie, T., Zhang, H., Smolen, M.D., 2003a. Pasture Phosphorus Management (PPM) Calculator Technical Documentation Version 1.0. Oklahoma State University, Stillwater, OK.

White, M.J., Storm, D.E., Stoodley, S., Smolen, M.D., 2003b. Modeling the Lake Eucha Basin using SWAT 2000. In: Proceedings of the TMDL Environ. Reg. 8-12 Nov. 2003. Albuquerque, NM. p. 536-542.

White, M.J., 2007. Development and Validation of a Quantitative Phosphorus Loss Assessment Tool. Oklahoma State University, Stillwater. PhD Dissertation Available at: <http://storm.okstate.edu/PPM./Mike\%20White\%20Dissertation\% 20Complete.pdf > (accessed 2.22.10).

White, M.J., Storm, D.E., Smolen, M.D., Zhang, H., 2009. Development of a quantitative pasture phosphorus management tool using the SWAT model. Journal of the American Water Resources Association 45, 397-406.

Whitis, G., 2002. Watershed Fish Production Ponds Guide to Site Selection And Construction. Southern Regional Aquaculture Center. Oklahoma State University, Stillwater, OK. Available at: <http://pods.dasnr.okstate.edu/docushare/ dsweb/Get/Document-1837/SRAC-102web.pdf > (accessed 10.03.08).

Williams, J.R., 1975. Sediment routing for agricultural watersheds. Water Resource Bulletin 11, 965-974. 